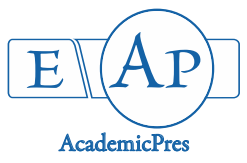

Ikhajiagbe B and Musa SI (2020)

Notulae Scientia Biologicae 12(3):683-692

DOI: $10.15835 / \mathrm{nsb} 12310777$

Research Article

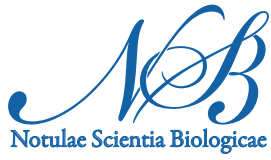

\title{
The effects of salicylic acid on the germination and early seedling growth of pigeon pea (Cajanus cajan)
}

\author{
Beckley IKHAJIAGBE ${ }^{1}$, Saheed I. MUSA ${ }^{1,2 *}$ \\ ${ }^{1}$ University of Benin, Edo State Nigeria, Faculty of Life Sciences, Department of Plant Biology and Biotechnology, \\ Nigeria;Beckley.ikhajiagbe@uniben.edu \\ ${ }^{2}$ Admiralty University of Nigeria Delta State Nigeria, Faculty of Science, Department of Biological Sciences, \\ Nigeria; Musa-biology@adun.edu.ng ("corresponding author)
}

\begin{abstract}
This study investigated the effects of salicylic acid (SA) on the germination and early seedling growth of Pigeon pea (Cajanus cajan L., Fabaceae). Pigeon pea were sown in soils containing $5 \mathrm{mg} / \mathrm{l}, 10 \mathrm{mg} / \mathrm{l}, 20 \mathrm{mg} / \mathrm{l}, 30$ $\mathrm{mg} / \mathrm{l}$ and $50 \mathrm{mg} / \mathrm{l} \mathrm{SA}$ and a control $(0 \mathrm{mg} / \mathrm{l})$. The treatment was applied to the plant for 6 weeks from the day of planting. It was observed that the leaflet area increased more in plants that received SA treatment in low concentration $(0 \mathrm{mg} / \mathrm{l}, 5 \mathrm{mg} / \mathrm{l}, 10 \mathrm{mg} / \mathrm{l}$ and $20 \mathrm{mg} / \mathrm{l})$ than in those with higher concentration $(30 \mathrm{mg} / \mathrm{l}$ and 50 $\mathrm{mg} / \mathrm{l})$. The same result was obtained in the total chlorophyll content of the leaves and in average height of the plant $(p<0.05)$. It was also observed that the number of leaves formed were more in plant that had little SA concentration. However, it was also discovered that at concentration below $10 \mathrm{mg} / \mathrm{l}$, the growth promoting effect of SA declined. The study presents supporting evidence that optimum SA concentration required for maximum seed germination and early seedling growth in $C$. cajan is $20 \mathrm{mg} / \mathrm{l}$. This finding will act as guide in the application of SA treatment in growing C. cajan.

Keywords: early seedlings; germination percentage; leaflet area; pigeon pea (Cajanus cajan); salicylic acid

\section{Introduction}

Salicylic acid (SA) is a naturally occurring endogenous plant-promoting hormone. It is a colourless and crystalline organic acid that can be extracted from different plant species, such as the bark of the willow tree. It plays a unique role in regulating plant physiological and morphological processes such as growth and development (Khodary, 2004; Huang et al., 2008), induction of flower (Coronado, 1998), root growth stimulation by inducing thermogenesis (Horvath et al., 2007), influences seed germination (Jumali et al., 2011), seedling establishment (Fatima et al., 2015), cell growth (Onkar et al., 2015) nutrient uptake and transport (Gunes et al., 2005) and respiration (Jadhav and Bhamburdekar, 2011). These regulatory processes have been achieved via SA-mediated control of major plant-metabolic processes, such as its involvement in mitogenactivated protein kinase (MAPK) regulation (Chai et al., 2014).
\end{abstract}


Over the years, SA has attracted attention from researchers due to its ability to activate plant growthstimulatory enzymes, synthesize flavonoid and other photosynthesis processes even under various biotic and abiotic stresses (Radhakrishnan and Balasubramanian, 2019; Zhao et al., 2019). Moreover, the ameliorating effects of SA have been well documented in many crops such as Vicia faba L. (Azooz, 2009), tomato (Tari et al., 2005) and maize (Gunes et al., 2007). Exogenous application of SA enhances the photosynthetic rate and also maintains the stability of membranes thereby improving the growth of plants irrespective of the abiotic growing condition (Miura and Tada, 2014). When applied, SA move directly to the soil, where it is trapped by the tap-roots and then translocated to different parts (Wang et al., 2011). According to Kazemi-Shahandashti et al. (2014), plants with deep taproots may have challenges or delay in SA usage, or in some other cases, more SA mixture may be needed for improved crops, especially at low/chilling temperatures. Plants such as $C$. cajan has been documented to have a deep tap root which extends upward to about $2 \mathrm{~m}$ and spread sideward by means of lateral roots (Natarajan and Willey, 1980).

Pigeon pea is well adapted to the tropics and subtropical regions of the world. Within the family (Fabaceae), C. cajan is the most cultivated and its seeds have become a common food in Asia and Africa (Miura and Tada, 2014). It can be cultivated on marginal land of low fertilizer content, though it cannot withstand drought and saline environments (Fatima et al., 2015). It is the second most cultivated legume in Nigeria and one of the most important pulse crops (Musa and Ikhajiagbe, 2019). C. cajan is an integral part of subsistence and rain fed farming system of the world and provides food, feed, fodder, and fuel wood (Patil et al., 2016). Immature seeds and pods of $C$. cajan are consumed as green vegetable. The seed coat together with the husk provides a valuable feed for animals (Zeven and Zhukovsky, 1975; Ambasta, 2004). Green leaves and tender branches act as fodder for livestock. The tall and erect Pigeon pea plants do not only provide food but also provide firewood for rural people (Sharma and Green, 1980).

Previous research has discussed the role of SA in promoting plant growth, for example Shakirova et al. (2003) reported that $S A$ induced increase of the resistance of wheat seedlings against salinity while Jadhav and Bhamburdekar, (2011) concluded that SA treatment of $50 \mathrm{ppm}$ concentration showed significant germination in all groundnut cultivars. Further, Singh et al. (2010) reported that nicotinamide adenine dinucleotide $(\mathrm{NADH})$ glutamate synthetase activity was stimulated by $1-1000 \mathrm{M} \mathrm{SA}$ in the leaf and by $50-100 \mathrm{M} \mathrm{SA}$ in the root tissues of maize seedlings. Kaur (2009) observed that SA has a stimulating effect on soybean Glycine max. According to (Canakci, 2011), $0.3 \mathrm{mM}$ application of SA produced prominent results on growth parameters of pepper seedlings. The current research is set up to investigate the effects of SA on germination and early seedling growth of $C$. cajan. The study will also suggest optimum concentration of SA required for seed germination and early seedling growth in the test plant.

\section{Materials and Methods}

\section{Preparation of seeds}

The seeds of pigeon pea were obtained from the Agricultural Development Program, Delta State of Nigeria. The seeds were sterilized with sodium hypochloride (1\%) for $5 \mathrm{~min}$ and then washed with distilled water in order to clean off the chlorine residue. Only healthy seeds were further selected for germination test. The deionized water used in this experiment was prepared using a deionizing equipment (Basic-Q15-IT, 2005, China). Loamy soil from a humus area at the botanic garden of the University of Benin (UNIBEN; $6.3931^{\circ} \mathrm{N}$, $5.6195^{\circ} \mathrm{E}$ ) was collected in a nursery bag and used for the nursery set up at the botanic garden of UNIBEN under optimum climatic and environmental condition as reported by (Musa and Ikhajiagbe, 2019).

\section{Preparation of $S A$}

Specific concentrations in milligrams were prepared after measured weights of SA produced following (Weissmann, 1991) were dissolved in measured volumes of deionized water. However, obtaining SA weight in 
milligrams was difficult, each treatment solution was converted to their respective equivalent in grams and liters. The concentrations were prepared for $5 \mathrm{mg}, 10 \mathrm{mg}, 20 \mathrm{mg}, 30 \mathrm{mg}$ and $50 \mathrm{mg}$ following: weight $(\mathrm{mg}) / 1000$. To determine the concentration in a said volume, the volume $(\mathrm{g} / \mathrm{l}) \mathrm{x}$ volume, therefore: $5 \mathrm{mg}=$ $5 \div 1000=0.005 \mathrm{~g} / \mathrm{l}$, Concentration in 4 liters $=0.005 \times 4=0.02 \mathrm{gl}^{-4} .150 \mathrm{ml}$ of the prepared SA solution was applied to each nursery bags at an interval of 4 days for 16 days. At $20^{\text {th }}$ day, $67 \mathrm{ml}$ was further applied.

\section{Sowing of seeds}

Six seeds of pigeon pea were sowed at the depth of about $5 \mathrm{~cm}, 2$ hours after the application of the prepared SA solution to the soils in the nursery bags, using a measuring cylinder.

\section{Germination and plant growth study}

Germination percentage (GP) was calculated following (ISTA, 2005) as:

$\mathrm{GP}=\frac{\text { Seed Germination }}{\text { Total seed sown }} \times 100$

C. cajan seeds were tested for viability following (AOSA, 2000). Germination records were taken from the fourth day after planting, everyday till the 8th day. Seedling height was measured using measuring tape $(\mathrm{cm})$ every week for five weeks after sowing. Number of all leaves were counted and recorded for week 2, 4 and 5. At week 5 after sowing, fresh and air-dried weight of the plant and the foliar weight were measured using analytical weighing balance (Equinox, Japan). Root length of the plant was measured at week 5 after sowing from the soil level to the terminal bud of the main roots. The total chlorophyll content of the leaves was determined according to Arnon et al. (1949) with slight modification by Musa and Ikhajiagbe (2019).as: total chlorophyll content $(\mathrm{mg} / \mathrm{gfw})=$ Chlorophyll a $(\mathrm{Chl}-\mathrm{a})+$ Chlorophyll $\mathrm{b}(\mathrm{Chl}-\mathrm{b})$. The leaflet area under each treatment was calculated by measuring their respective length and breadth.

Area of leaf $=$ Length $\times$ breadth $\times 0.75$.

\section{Statistical analysis}

Mean and standard error of data was calculated using GENSTAT, the $8^{\text {th }}$ edition. Results were presented as mean of the three replicates and separated using two-way analysis of variance test at $\mathrm{p}<0.05$ (Ogbeibu, 2005).

\section{Results and Discussion}

Effect of salicylic acid on seed germination percentage and root length:

Results presented in (Table 1) shows a high significant effect of SA on the germination percentage and root length of $C$. cajan seeds. At day 4 and 6, the control has the least germination percentage of $16 \%$ and $27 \%$ respectively, while the SA treatment of $(20 \mathrm{mg} / \mathrm{l})$ showed highest percentage germination in the study intervals. The highest treatment of $S A(50 \mathrm{mg} / \mathrm{l})$ showed the least percentage germination at day 8 after sowing. With this, it is likely that $(20 \mathrm{mg} / \mathrm{l})$ of $S A$ is the required treatment for optimum seed germination in $C$. cajan. This result shows the stimulatory effects of SA on seed germination. The study agreed with the work (Rajjou et al., 2006) who reported the stimulatory effect of SA in seed germination of Arabidopsis. (Kaydan et al., 2007) and (Shakirova et al., 2003) have used SA to increase germination and seed vigor in wheat. Also, the highest root length $(19.93 \mathrm{~cm})$ was obtained from the $(20 \mathrm{mg} / \mathrm{l}) \mathrm{SA}$ treatment, meanwhile the length reduces as the concentration increases. This research is consistent with the work of (Demir et al., 2006) who reported priming seeds with SA increased the root length of Brassica napus $\mathrm{L}$. 
Table 1. Germination percentage and root length of pigeon pea treated salicylic acid

\begin{tabular}{|c|c|c|c|c|c|c|}
\hline \multirow{2}{*}{$\begin{array}{c}\text { Salicylic acid } \\
\text { treatment }(\mathrm{mg} / \mathrm{l})\end{array}$} & \multicolumn{5}{|c|}{ Germination percentage (\%) } & \multirow{2}{*}{$\begin{array}{c}\text { Root length } \\
(\mathrm{cm})\end{array}$} \\
\hline & Day 0 & Day 1 & Day 4 & Day 6 & Day 8 & \\
\hline $0 \mathrm{mg} / \mathrm{l}$ & 0 & 0 & $16.67 \pm 18.26^{\mathrm{ns}}$ & $27.78 \pm 22.78$ & 66.67 & $11.00 \pm 0.44^{\mathrm{n}}$ \\
\hline $5 \mathrm{mg} / \mathrm{l}$ & 0 & 0 & $47.22 \pm 6.81^{*}$ & $75 \pm 9.13^{*}$ & $100^{*}$ & $11.80 \pm 0.40^{*}$ \\
\hline $10 \mathrm{mg} / \mathrm{l}$ & 0 & 0 & $69.44 \pm 34.02^{*}$ & $77.78 \pm 13.61^{*}$ & $100^{*}$ & $16.00 \pm 0.40^{*}$ \\
\hline $20 \mathrm{mg} / \mathrm{l}$ & 0 & 0 & $88.89 \pm 8.61^{*}$ & $100 \pm 0.00^{*}$ & $100^{*}$ & $19.93 \pm 0.19^{*}$ \\
\hline $30 \mathrm{mg} / \mathrm{l}$ & 0 & 0 & $38.89 \pm 8.61^{*}$ & $63.89 \pm 12.55^{*}$ & $80.55^{*}$ & $11.40 \pm 0.78^{*}$ \\
\hline $50 \mathrm{mg} / \mathrm{l}$ & 0 & 0 & $16.67 \pm 14.91^{\mathrm{ns}}$ & $30.56 \pm 19.48^{*}$ & $58.34^{*}$ & $10.73 \pm 0.56^{\mathrm{n}}$ \\
\hline
\end{tabular}

Results were presented as mean and standard error of three replicates. ${ }^{*}=$ difference statistically significant at $p<0.05$. ns= no significant difference.

Effect of salicylic acid on seedling height and number of leaves:

Table 2 presents the average seedling height and number of leaves of $C$. cajan treated with different concentrations of SA from the $2^{\text {nd }}$ to $5^{\text {th }}$ weeks after sowing (WAS). The results showed a significant increase (at $P>0.05$ ) in the seedling height and leave number of the test plant with the application of the SA. However, the $20 \mathrm{mg} / \mathrm{l}$ concentration of SA proved to be $10-30 \%$ higher than other treatments at all intervals. There was a reduction in the seedling height and leaf number from $30 \mathrm{mg} / \mathrm{l}$ to $50 \mathrm{mg} / \mathrm{l}$. This research agrees with a study by (Tooraj et al., 2014) on the effect of Brassica napus seed priming with SA. In the current study, $20 \mathrm{mg} / \mathrm{l} \mathrm{SA}$ treatment proved to have optimum effect on $C$. cajan. This result disagrees with the work of (Oknar et al., 2015) where he suggested $30 \mathrm{mg} / \mathrm{l}$ of SA as the perfect treatment for optimum germination of Phaseolus vulgaris and Cicer arietinum. Najafian et al. (2009) concluded that spraying Rosmarinus officinalis L. with three levels of SA $(450,300$, and 150$) \mathrm{mg} / \mathrm{l}$ resulted in a significant increase in growth rates compared to untreated plants.

Table 2. Average seedling height and leaf number of $C$. cajan grown in soils with various concentrations of SA

\begin{tabular}{|c|c|c|c|c|c|c|c|}
\hline \multirow{2}{*}{$\begin{array}{c}\text { SA } \\
\text { treatments } \\
(\mathrm{mg} / \mathrm{l})\end{array}$} & \multicolumn{4}{|c|}{ Plant height $(\mathrm{cm})$} & \multicolumn{3}{c|}{ Number of leaves formed } \\
\cline { 2 - 8 } & $2^{\text {nd }}$ WAS & $3^{\text {rd }}$ WAS & $4^{\text {th }}$ WAS & $5^{\text {th }} W A S$ & $2^{\text {nd }} W A S$ & $4^{\text {th }} W A S$ & $5^{\text {th }}$ WAS \\
\hline 0 & $7.75 \pm 0.4$ & $15.63 \pm 0.4$ & $22.53 \pm 0.7$ & $30.96 \pm 0.68$ & $6.50 \pm 0.54$ & $14.67 \pm 0.54$ & $21.33 \pm 1.03$ \\
\hline 5 & $8.32 \pm 0.2$ & $16.4 \pm 0.40$ & $24.08 \pm 0.40$ & $32.62 \pm 0.76$ & $7.50 \pm 1.05$ & $15.00 \pm 0.89$ & $21.50 \pm 1.05$ \\
\hline 10 & $8.92 \pm 0.17$ & $17.18 \pm 0.36$ & $25.25 \pm 0.39$ & $33.10 \pm 0.51$ & $8.17 \pm 0.75$ & $17.17 \pm 0.75$ & $22.5 \pm 1.05$ \\
\hline 20 & $10.27 \pm 0.36$ & $19.5 \pm 0.42$ & $28.22 \pm 0.54$ & $36.72 \pm 0.6$ & $9.00 \pm 0.89$ & $20.33 \pm 0.82$ & $27.67 \pm 1.03$ \\
\hline 30 & $9.2 \pm 0.50$ & $8.8 \pm 0.39$ & $21.52 \pm 0.64$ & $29.72 \pm 0.56$ & $7.50 \pm 0.54$ & $16.00 \pm 0.89$ & $22.17 \pm 1.17$ \\
\hline 50 & $7.35 \pm 0.19$ & $15.08 \pm 0.31$ & $19.72 \pm 0.47$ & $27.2 \pm 0.65$ & $6.00 \pm 0.63$ & $13.33 \pm 0.82$ & $17.67 \pm 1.03$ \\
\hline
\end{tabular}

\section{Effects of salicylic acid on plant developmental parameters:}

Figure 1 to 5 present the effects of different concentrations of $S A$ on yield parameters of $C$. cajan. Figure 1 showed a significant increase in the number of branches with the application of $S A$ at low concentrations (20 $\mathrm{mg} / \mathrm{l}, 10 \mathrm{mg} / \mathrm{l}$ and $5 \mathrm{mg} / \mathrm{l}$ ) compared to the high concentrations ( $30 \mathrm{mg} / \mathrm{l}$ and $50 \mathrm{mg} / \mathrm{l}$ ). However, the $20 \mathrm{mg} / \mathrm{l}$ treatment of SA has the highest number of stem branches, while the $50 \mathrm{mg} / 1$ treatment of SA showed least number of stem branches. This may be attributed to the ability of SA to influence plant regulatory processes via the SA-mediated MAPK regulation (Chai et al., 2014). Exogenously applied SA was reported to improve growth and stem branches in several crops including Oryza sativa and Phaseolus vulgaris (Zengin, 2014). 


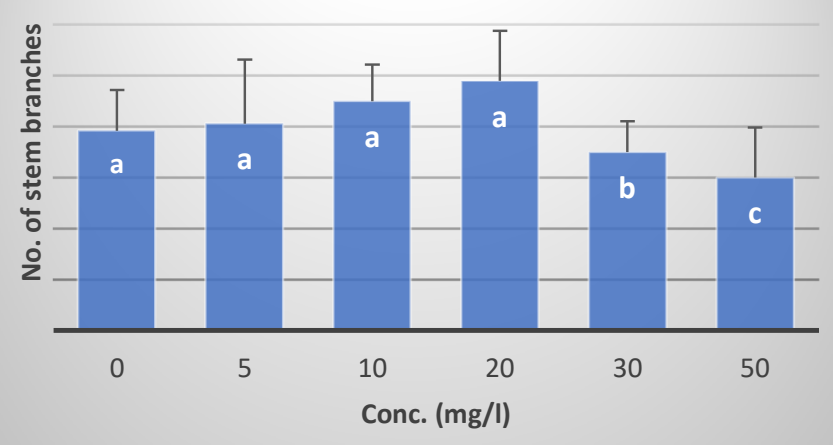

Figure 1. Number of stem branches of Cajanus cajan grown in soils treated with SA at different concentrations

Different alphabet $(\mathrm{a}-\mathrm{c})$ means results are significantly difference at $(\mathrm{P}=0.05)$.

Figure 2 showed significant increase in fresh and dry weight of C. cajan with the application of SA at 20 $\mathrm{mg} / \mathrm{l}$ concentration compared to the other $S A$ treatment levels. However, there was no significant difference in the dry weight of $C$. cajan between the $50 \mathrm{mg} / \mathrm{l}$ concentration of SA and the control. Furthermore, the application of $50 \mathrm{mg} / \mathrm{l}$ of SA showed lowest fresh weight of $C$. cajan. The control performed better than the 50 $\mathrm{mg} / \mathrm{l}$ concentration of SA at (4:2). This is likely that the $50 \mathrm{mg} / \mathrm{l}$ concentration of SA negatively influenced certain regulatory processes in C. cajan. According to Zhang et al. (2015), the SA-induced growth stimulation in plants differs in different plants at different concentration levels. Growth of Zea mays was negatively influenced when exposed to $25 \mu \mathrm{M}$ of SA every day for 50 days (Krantev et al., 2008).

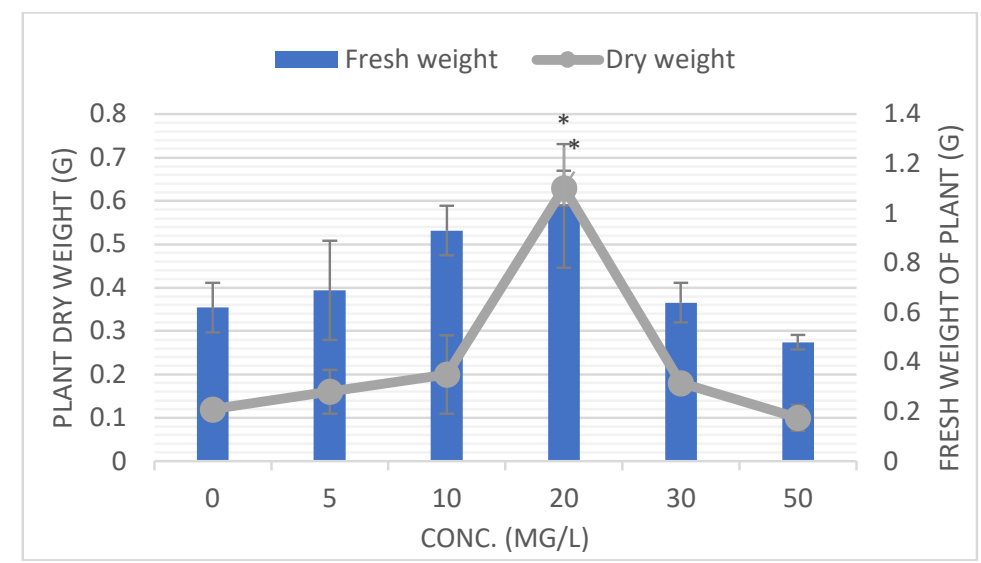

Figure 2. Fresh and dry weight of Cajanus cajan grown under the influence of SA of varying concentration ${ }^{*}$ means significant difference at $\mathrm{p}=0.05$.

Figure 3 depicts the leaf area of the test plant with the application of SA. It was observed that there was no significant different between the SA treatments at low concentration $(20 \mathrm{mg} / \mathrm{l}, 10 \mathrm{mg} / \mathrm{l}$ and $5 \mathrm{mg} / \mathrm{l})$ and the control. Meanwhile, a significant reduction in leaf area was detected with the application of SA at higher concentration $(30 \mathrm{mg} / \mathrm{l}$ and $50 \mathrm{mg} / \mathrm{l})$. This indicated that the $S A$ at low concentration has promoted the leaf area by stimulating the translocation of different nutrients, activating cell division and biosynthesis of organic food. This report is in line with the work of (Radford, 1992). Zhou et al. (2009) also reported that SA increased the leaf area in Sugar cane. In this research, the $20 \mathrm{mg} / \mathrm{l}$ concentration of SA was observed to have the highest leaf area, while the $50 \mathrm{mg} / \mathrm{l}$ of $S A$ was the lowest. 


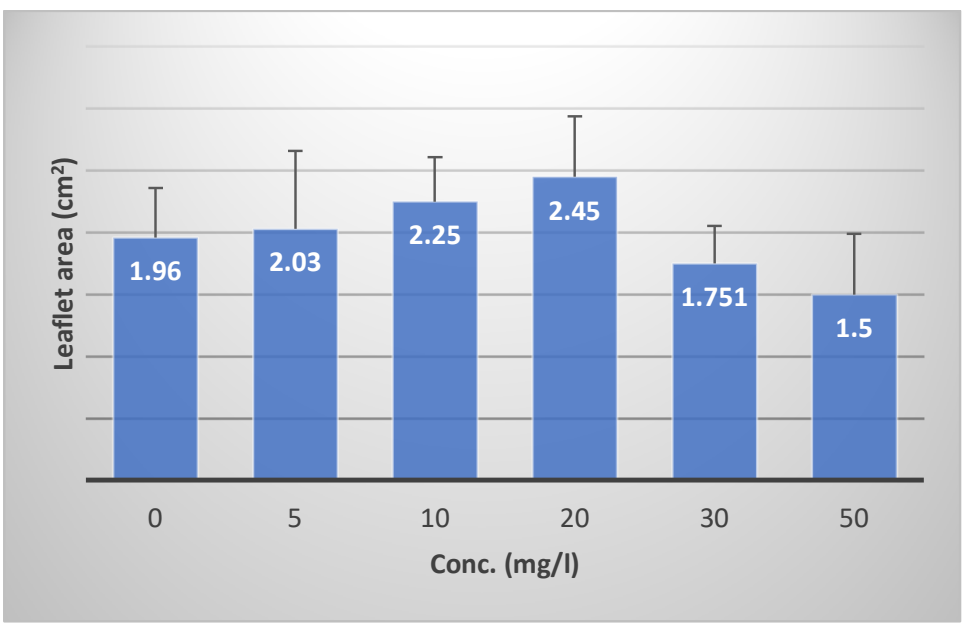

Figure 3. Area of leaflets of Cajanus cajan grown in soils treated with different concentration of SA

Figure 4 shows the total fresh foliar weight. The least foliar weight was observed in the highest concentration $(50 \mathrm{mg} / \mathrm{l})$ of SA, while the highest foliar weight was observed in the $20 \mathrm{mg} / \mathrm{l}$ concentration of SA. Similar result was obtained in the dry foliar weight (Figure 4) and chlorophyll content (Figure 5). From all the assayed parameters above, $20 \mathrm{mg} / \mathrm{l}$ concentration of SA has proven to show the optimum effect on C. cajan. This may be because SA has the ability to synthesize carotenoids, xanthophylls and the ratio of de-oxidation, thereby increasing the chlorophyll content. Recent evidences also suggested SA as an important regulator of photosynthesis, photosystems II (PSII), photosynthetic pigments and the activity of enzymes such as Rubisco and Carbonic anhydrase (Al-Whaibi et al., 2012; Zhang et al., 2015) This result agreed with the work of Tayab, (2003) and Gunes et al. (2005) for maize and Chen et al. (2007) for O. sativa. However, the decrease in Chlorophyll content in plant with higher concentration of $S A(30$ and $50 \mathrm{mg} / \mathrm{l})$ is consistent with the work of Moharekar et al. (2003) which states that the total Chlorophyll a and b content decreases significantly in wheat at a higher concentration of SA (Figure 5).

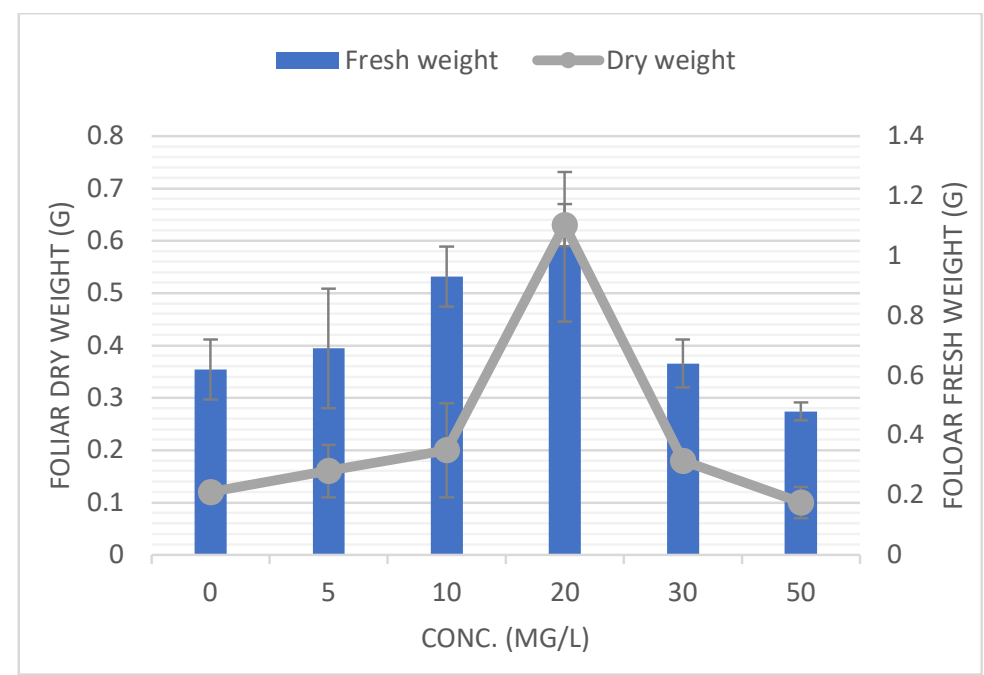

Figure 4. Fresh and dry foliar weight of C.cajan grown in soils with different concentration of SA 


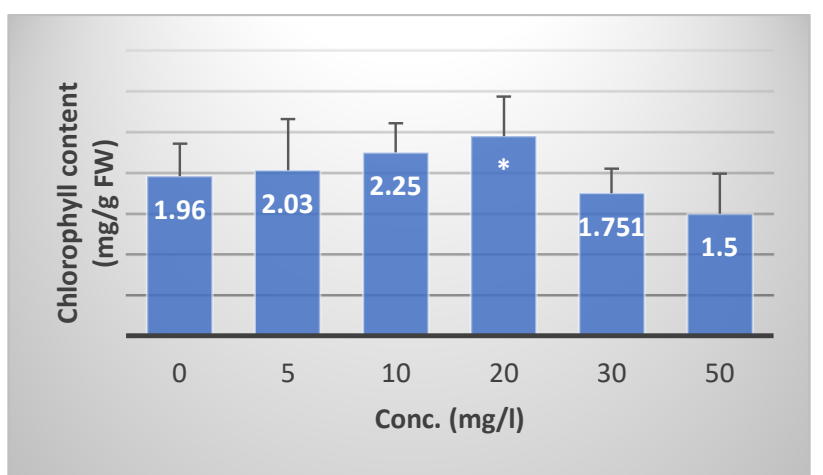

Figure 5. Chlorophyll content of C. cajan leaves treated with different SA concentrations * means significant increase.

\section{Conclusions}

The results from this study showed the stimulatory effect of seed germination and early seedling growth of $C$. cajan by SA. The application of $S A$ at low concentrations $(20 \mathrm{mg} / \mathrm{l}, 10 \mathrm{mg} / \mathrm{l}$ and $5 \mathrm{mg} / \mathrm{l})$ enhanced and improved all assayed parameters in the test plant. However, the $20 \mathrm{mg} / \mathrm{l}$ concentration of SA had the highest enhancement effect while higher concentrations showed reduced effect. Based on these results, it can be concluded that $20 \mathrm{mg} / \mathrm{l}$ concentration of SA have more positive effects on C. cajan germination and early seedling growth than higher concentrations. Therefore, application of $20 \mathrm{mg} / \mathrm{l}$ concentration of SA is recommended for optimum seed germination and early seedling growth of $C$. cajan. This finding will act as a guide in the application of SA treatments in growing C. cajan.

\section{Authors' Contributions}

BI designed the study. BI and SIM executed the study. BI analyzed the data. BI and SIM prepared the drafts and SIM wrote the final manuscript. Both authors read and approved the final manuscript.

\section{Acknowledgements}

The researchers are grateful to the entire students and staff in Environmental Biotechnology and Sustainable Research (EBSR) Group Lab of the Department of Plant Biology and Biotechnology, University of Benin, Benin City and some colleagues from Admiralty University of Nigeria for all their contributions during the field study.

\section{Conflict of Interests}

The authors declare that there are no conflicts of interest related to this article. 


\section{References}

Al-Whaibi M, Siddiqui M, Basalah M (2012). Salicylic acid and calcium-induced protection of wheat against salinity. Protoplasma 249(3):769-778. https://doi.org/10.1007/s00709-011-0322-1

Ambasta S (2004). National Institute of Science Communication. The useful plants of India. $4^{\text {th }}$ ed. New Delhi pp 94-95.

Anaya F, Fghire R, Wahbi S, Loutfi K (2015). Influence of salicylic acid on seed germination of Vicia faba L. under salt stress. Journal of the Saudi Society of Agricultural Sciences 17:1-8. https://doi.org/10.1016/j.jssas.2015.10.002

AOSA (2000). Association of official seed analysts. Rules for testing seeds. Proceedings of the Association of Official Seed Analysts 60(2):39.

Apogee Instruments Incorporated (2007). How it works? Retrieved 2007 June 26 from http://www.apogeeinstruments.com

Arnon D (1949). Copper enzyme polyphenoloxide in isolated chloroplast in Beta vulgaris. Journal of Agriculture 2:1-9. https://doi.org/10.1104/pp.24.1.1

Azooz MM (2009). Salt stress mitigation by seed priming with salicylic acid in two faba bean genotypes differing in salt tolerance. International Journal of Agriculture and Biology 11:343 350.

Canakci C (2011). Effects of salicylic acid on growth, biochemical constituents in pepper (Capsicum annuum L.) seeddlings. Pakistan Journal of Biological Sciences 14(4):300-304. https://doi.org/10.3923/pjbs.2011.300.304

Chai J, Liu J, Zhou J, Xing D (2014). Mitogen-activated protein kinase 6 regulates NPR1 gene expression and activation during leaf senescence induced by salicylic acid. Journal of Experimental Botany 65:6513-6528. https://doi.org/10.1093/jxb/eru369

Chen J, Zhu C, Li L, Sun Z (2007). Effects of exogenous salicylic acid on growth and $\mathrm{H}_{2} \mathrm{O}_{2}$-metabolizing enzymes in rice seedlings under lead stress. Journal of Environmental Sciences 19:44-49. https://doi.org/10.1016/s10010742(07)60007-2

Coronado MA, Trejo-Lopez G, Karque-Saavedro A (1998). Effect of salicylic acid on the growth of roots and shoots in soybean. Plant Physiology and Biochemistry 36:563-565.

El-Tayeb MA (2005). Response of barley grains to the interactive effect of salinity and salicylic acid. Plant Growth Regulation 45:215-224. https://doi.org/10.1007/s10725-005-4928-1

Görgényi Miklósné Tari I, Csiszár J, Horváth E, Poór P, Takács Z, Szepesi Á (2015). The alleviation of the adverse effects of salt stress in the tomato plant by salicylic acid shows a time-and organ-specific antioxidant response. Acta Biologica Cracoviensia Series Botanica 57(1):21-30.

Grover O, Gaur I, Mitra J, Paul P (2015). Effect of salicylic acid on germination of Phaseolus vulgaris and Cicer arietinum under salt stress. Trends in Biosciences 8(16):4142 4147.

Gunes A, Inal A, Alpaslam M, Erslan F, Bagsi E, Cicek N (2007). Salicylic acid induced changes on some physiological parameters symptomatic for oxidative stress and mineral nutrition in maize (Zea mays) grown under salinity. Journal of Plant Physiology 164(6):728-736. https://doi.org/10.1016/j.jplph.2005.12.009

Gunes A, Inal A, Alpaslan M, Cicek N, Guneri E, Eraslan F, Guzelordu T (2005). Effects of exogenously applied salicylic acid on the induction of multiple stress tolerance and mineral nutrition in maize (Zea mays L.). Archives of Agronomy and Soil Science 51:687-695. https://doi.org/10.1080/03650340500336075

Horvath E, Szalai G, Janda T (2007). Induction of abiotic stress tolerance by salicylic acid Signaling. Journal of Plant Growth Regulator 26:290-300. https://doi.org/10.1007/s00344-007-9017-4

Huang RH, Liu JH, Lu YM, Xia RX (2008). Effect of salicylic acid on the antioxidant system in the pulp of 'Cara cara' navel orange (Citrus sinensis (L.) Osbeck) at different storage temperatures. Postharvest Biology and Technology 47:168-175.

ISTA (2005). International rules for seed testing. International Seed Testing Association (ISTA), Seed Science and Technology.

Jadhav SH, Bhamburdekar SB (2011). Effect of salicylic acid on germination performance in groundnut. International Journal of Applied Biology and Pharmaceutical Technology 2(4):224-227.

Jumali SS, Said IM, Zainal Z (2011). Genes induced by high concentration of salicylic acid in (Mutragyna speciosa). Australian Journal of Crop Science 5:296-303.

Kaur P, Ghai N, Sangha M (2009). Induction of thermotolerance through heat acclimation and salicylic acid in Brassica species. African Journal of Biotechnology 8:619-625. https://doi.org/10.5897/AJB2009.000-9104

Kaya MD, Okçu G, Atak M, Çikili Y, Kolsarici Ö (2006). Seed treatment to overcome salt and drought stress during germination in sunflower (Helianthus annuus L.). European Journal of Agronomy 24:291-295. 
Kaydan D, Yagmur M, Okut N (2007). Effects of salicylic acid on the growth and some physiological characters in salt stressed wheat (Triticum aestivum L.). Torim Bilimieri Dergisi 13(2):114-119.

Kazemi-Shahandashti S, Maali-Amiri R, Zeiali H, Khazaei M, Talei A, Ramezanpour S (2014). Effect of short-term cold stress on oxidative damage and transcript accumulation of defense-related genes in chickpea seedlings. Journal of Plant Physiology 171:1106-1116. https://doi.org/10.1016/j.jplph.2014.03.020

Khodary SEA (2004). Effect of salicylic acid on the growth, photosynthesis and carbohydrate metabolism in salt stressed maize plants. International Journal of Agriculture and Biology 6(1):5-8. https://doi.org/10.1.1.322.9285

Krantev A, Yordanova R, Janda T, Szalai G, Popova L (2008). Treatment with salicylic acid decreases the effect of cadmium on photosynthesis in maize plants. Journal of Plant Physiology 165:920-931. https://doi.org/10.1016/j.jplph.2006.11.014

Mir-Mahmoodi T, Golizadeh SK, Khaliliqhdam N, Yazdanseta S (2014). The effect of salicylic acid on rate germination and seedling establishment on rapeseed (Brassica napus L.). International Journal of Agriculture Innovations and Research 2(6):2319-1473.

Miura K, Tada Y (2014). Regulation of water, salinity and cold stress responses by salicylic acid. Frontiers in Plant Science 5:4. https://doi.org/10.3389/fpls.2014.00004

Moharekarst I, Moherekar SD, Hara T, Taraka R, Tanak A, Chavan PD (2003). Effect of salicylic acid on chlorophyll and carotenoid contents of wheat and moong seedlings. Photosynthetica 41:315-317. https://doi.org/10.1023/B\%3APHOT.0000011970.62172.15

Musa SI, Ikhajiagbe B (2019). Bioaccumulation of heavy metals by Vigna unguiculata (Cowpea) grown on Olusosun dumpsite, Lagos Nigeria. Journal of Underutilized Legumes 1(1):91-98.

Najafian S, Khoshkhui M, Vahid T (2009). Effect of salicylic acid and salinity in rosemary (Rosmarinus officinalis L.): Investigation on changes in gas exchange, water relations, and membrane stabilization. Advances in Environmental Biology 3(3):322-328.

Natarajan M, Willey R (1980). Sorghum-pigeon pea inter cropping and the effect of plant population density on growth and yield. Journal of Agricultural Science 92:513-526.

Patil DB, Shewale AB, Bhamburdekar S (2016). Influence of salicylic acid on seed germination of pigeon pea (Cajanus cajan (L.). International Research Journal of Engineering and Technology 3(8):135-137.

Radford B (1992). Growth analysis formular-their use and abuse. Crop Science 7:171-175.

Radhakrishnan N, Balasubramanian R (2009). Salicylic acid induced defense responses in Curcuma longa (L.) against Pythium aphanidermatum infection. Crop Protection 28:974-979. https://doi.org/10.1016/j.cropro.2009.07.010

Rajjou L, Belghazi M, Huhust R, Robin C, Moreau A, Job C, Job D (2006). Proteomic investigation of the effect of salicylic acid on Arabidiopsis seed germination and establishment of early defense mechanism. Plant Physiology 141:910-923. https://doi.org/10.1104/pp.106.082057

Shakirova F, Sakhabutdinova A, Bezrukova M, Fatkhutdinova R, Fatkhudinova DR (2003). Changes in the hormonal status of wheat seedlings induced by salicylic acid and salinity. Plant Science 164:317-322.

Sharma D, Green JM (1980). Pigeon pea. In: Fehr WR, Hadley H (Eds). Hybridization of crop plants.

Singh P, Chaturvedi V, Bose B (2010). Effects of salicylic acid on seedling growth and nitrogen metabolism in cucumber (Cucumis sativus L.). Journal of Stress Physiology \& Biochemistry 6:103-113. https://doi.org/10.1080/11263504.2011.602991

Wang Y, Mopper S, Hasentein K (2011). Effect of salinity on endogenous ABA, IAA, JA, and SA in Iris hexagona. Journal of Chemical Ecology 27:327-342. https://doi.org/10.1023/a:1005632506230

Weissmann G (1991). Aspirin. Scientific American 264:84-90.

Yildirim E, Turan M, Guvenc I (2008). Effect of foliar salicylic acid applications on growth, chlophyll and mineral content of cucumber grown under salt stress. Journal of Plant Nutrition 31(3):593-612. https://doi.org/10.1080/01904160801895118

Zengin F (2014). Exogenous treatment with salicylic acid alleviating copper toxicity in bean seedlings. Proceedings of the National Academy of Sciences, India Section B: Biological Sciences 84:749-755. https://doi.org/10.1007/s40011013-0285-4

Zeven AC, Zhukovsky PM (1975). Dictionary of cultivated plants. In: Huxby J (Ed). The New Systematics. Oxford University. London, UK pp 549-566. 
Zhang Y, Xu S, Yang S, Chen Y (2015). Salicylic acid alleviates cadmium-induced inhibition of growth and photosynthesis through upregulating antioxidant defense system in two melon cultivars (Cucumis melo L.). Protoplasma 252:911-924. https://doi.org/10.1007/s00709-014-0732-y

Zhou LY, Chen JL, Chen DF, Sun JR, Liu Y, Tian Z (2009). Biochemical and molecular characterization of Sitobion avenae-induced wheat defense responses. Crop Protection 28:435-442. https://doi.org/10.1016/j.cropro.2009.01.005
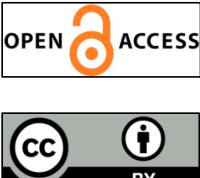

The journal offers free, immediate, and unrestricted access to peer-reviewed research and scholarly work. Users are allowed to read, download, copy, distribute, print, search, or link to the full texts of the articles, or use them for any other lawful purpose, without asking prior permission from the publisher or the author.

License - Articles published in Notulae Scientia Biologicae are Open-Access, distributed under the terms and conditions of the Creative Commons Attribution (CC BY 4.0) License.

(c) Articles by the authors; SHST, Cluj-Napoca, Romania. The journal allows the author(s) to hold the copyright/to retain publishing rights without restriction. 